\title{
リービッヒ改良法による炭素及び水素の定量の際の 吸収瓶の恒量条件
}

\author{
斉藤 陽 ，市田 正次*
}

(1985 年 9 月 7 日受理)

\begin{abstract}
著者らが開発した炭素及び 水素定量のリービッヒ改良法における恒量化などの問題について検討し た.この改良法は燃料試料の爆燃を防止するため, 試料をーリウムガス導入下, 急速に加熱分解し, 発 生した揮発成分を加熱酸化銅で酸化することを特徵としており，以下酸素で燃焼を行い水及び二酸化炭 素の吸收質量によって定量することは従来のリービッヒ法と同じである。本改良法は温度条件はリービ ッ七法と, 燃焼時の酸素流速や吸収瓶はシェフィールド高温法と同じであり, 熱ガス導入後, 乾燥空気 あるいは酸素を導入する恒量操作を必要とするが，導入ガスの乾燥が不十分の場合には水分及び二酸化 炭素吸収瓶の吸収剂の活性化が起こり恒量化を困れなくなる。よって導入酸素の水分を完全に除去する ことが必要である，又この活性化はリン酸蒸気によっても起こる.
\end{abstract}

\section{1 緒言}

石炭類及びュークス類の炭素・水素定量方法はリービ ッヒ法とシェフィールド高温法が JIS 法1)で, 又国際規 格では ISO 法23)で各々規定されている. 両方法とも定 量の原理は同じで，試料の燃焼によって生成する水分及 び二酸化炭素を各々過塩素酸マグネシウム粒(水吸収瓶) と水酸化ナトリウム粒（二酸化炭素吸収瓶）に吸收させ て定量する.

リービッ七法は基準になる方法として従来一般に用い られてきたが，定量に約 2 時間を必要とし，又窒素酸化 物の影響で高值を示す傾向がある.

シェフィールド高温法は窒素酸化物の影響むなく, 分 析所要時間も約 40 分間であるが, 燃狫温度が $1350^{\circ} \mathrm{C}$ と高く, 揮発性の試料では危険であり, 我が国ではほと んど採用されていない。

一方, 炭素・水素・窒素を同時に分析できる差動熱伝 導率法を原理とした装置が市販されており, 広く用いら れている. しかしこの機器分析法は試料の量り取り量が 2〜3 mg と少ないため, 石炭・コークスなど灰分を含有

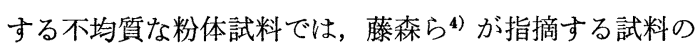
粒度と量り取り量との関係からみて分析精度上問題があ る.

著者らは以上のことから，燃料の炭素・水素定量方法

*日本鋼管 (株) 中央研究所：210 神奈川県川崎市川 崎区南渡田町 1-1
としてリービッ七改良法を確立した。リービッ七法では 酸素のみを用いて試料を燃焼させるのに対して，本改良 法では試料をへリウム導入下で急速加熱し，揮発成分を $800^{\circ} \mathrm{C}$ の酸化銅の加熱帯に吹き付けて酸化し，次いで 酸素を導入して完全然焼させることを特徵としており, 揮発性の試料でも爆然の危険はなく, 分析所要時間も約 20 分間である. この発想を具体化し分析法として確立 するために行った諸条件の 検討結果については既に報 告5)している.

本法は従来のリービッ七法と測定条件を異にするた め, 分析方法確立後も恒量化などの問題について新たな 解明を必要とした. 又水分や揮発分の含量の高い低石炭 化度炭や揮発性油の試料の取り扱いも問題であった. 以 下これらの検討内容について報告する.

$$
2 \text { 実験 }
$$

\section{1 装 是}

Fig. 1 亿示した系統図に打いて，石英燃焼管はフラ ッシュヒーター部 $(\mathrm{FH})$, 酸化炉 $(\mathrm{CF})$, 精製炉 (AF) を通過しており, 外径 $18 \mathrm{~mm} \phi$, 全長 $1000 \mathrm{~mm}$ である が，Fig. 4 の翰燥管 (二重管)を取り付ける場合には $1200 \mathrm{~mm}$ とする. $\mathrm{CF}$ 炬及び $\mathrm{AF}$ 炉の約 2 分の 1 の線 まで $420 \mathrm{~mm}$ にわたって針状酸化銅を充てんし， AF 炬 の吸収瓶よりに $130 \mathrm{~mm}$ にわたって活性酸化コバルト と銀粒の混合物を充てんする. 又 Fig. 2 に実験に用い た吸收瓶を示す.これは JIS 法》のシェフィールド高温 


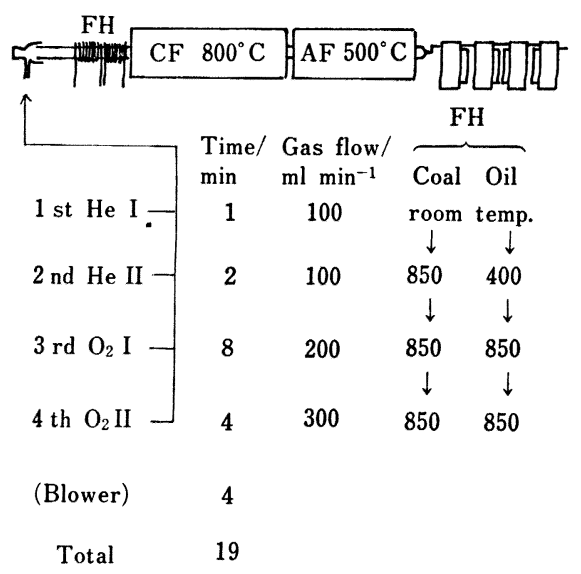

Fig. 1 Flow sheet of improved Liebig method $\mathrm{AF}$ : absorption furnace; $\mathrm{CF}$ : combustion furnace; FH : flash heater

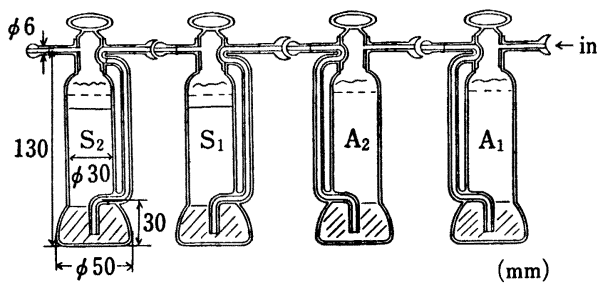

Fig. 2 Connected absorption bottles

法で規定されたものであり， $\mathrm{A}_{1}, \mathrm{~A}_{2}$ (水吸収瓶) $\mathrm{S}_{1}, \mathrm{~S}_{2}$ (二酸化炭素吸収瓶) の順に連結し，定量には $A_{1}, S_{1}$ の みを用い, $\mathrm{A}_{1}, \mathrm{~S}_{1}$ が飽和した際， $\mathrm{A}_{2}, \mathrm{~S}_{2}$ を前に繰り上 げて使用するが，この予備的な連結のため， $\mathrm{A}_{2}, \mathrm{~S}_{2}$ の吸 収瓶は 2 回の熱ガス導入, 乾燥酸素導入の恒量化操作で 恒量とすることができる.

\section{2 試 薬}

無水過塩酸マグネシウム粒: キシダ化学製，元素分析 用, $0.7 \sim 1.5 \mathrm{~mm}$

水酸化ナトリウム粒: メルク製, 元素分析用, $1.5 \sim$ $3.0 \mathrm{~mm}$

酸化銅：メルク製，元素分析用， $\phi 0.65 \sim(2 \sim 4) \mathrm{mm}$ 活性酸化コバルト：キシダ化学製サルフィクス，8〜 20 メッシュ

銀粒：キシダ化学製，20〜30 メッシュ

二酸化マンガン：キシダ化学製, 元素分析用, 6 〜 10 メッシュ

\section{3 操 作}

Fig. 1 の系統図に従って述べる.
気乾試料 $0.2 \mathrm{~g}$ を石英ボートに量り取り, フラッシュ ヒーター $(\mathrm{FH})$ の位置に插入する. この燃焼管には恒 量化操作がすみ，質量を測定した水吸収瓶及び二酸化炭 素吸収瓶が取り付けてある。最初にへリウム I $(100 \mathrm{ml} /$ min) 1 分間流し，系内の空気を置換し，次いでへリ ウム II $(100 \mathrm{ml} / \mathrm{min})$ 導入下, フラッシュヒーターの 電源を入れ，約 2 分間で $850^{\circ} \mathrm{C}$ まで昇温させる．次い で酸素 I $(200 \mathrm{ml} / \mathrm{min})$ を 8 分間更に酸素 II (300 ml/ min）を 4 分間流した後，再びヘリゥム $(50 \mathrm{ml} / \mathrm{min})$ に 切り替え, フラッシュヒーターの電源を切り, ブロワー で泠却する. 次いで吸収瓶を取り外し, 吸収瓶に乾燥酸 素 $(200 \mathrm{ml} / \mathrm{min}) を 10$ 分間導入して恒量化を図った後 質量を測定し, 水吸収瓶及び二酸化炭素吸収瓶の増量か ら炭素及び水素の定量值（wt％）を求める.

\section{3 結果と考察}

\section{1 吸収瓶の恒量化の検討}

3.1.1 酸素の吸着之脱離 吸収瓶の恒量化操作につ いて，リービッヒ法では吸収剂を充てんしたU字管に熱 ガスを導入後, 取り外し泠却するという操作の繰り返し で恒量化を行っている. 又シェフィールド高温法では熱 ガス導入後の吸収瓶を取り外し，乾燥空気を導入して恒 量化を行っている.

本法の場合，温度条件はリービッヒ法と又ガス流速や 吸収瓶はシェフィールド高温法と同じであるので，この 乾燥空気を導入する操作の必要性の有無を確認する実験 を行った.すなわち Fig. 2 で示した水吸収瓶と二酸化 炭素吸収瓶を燃焼管の出口に連結し, 試料の燃焼は行わ ず，吸収瓶に熱ガスを導入後，取り外し放冷後ひょう量 するといら操作を繰り返した. 結果は Table 1 の左の 欄に示すが，質量の増減が交互に起こり，かつ計 7 回の 繰り返しの総計は負の值を示した.

この実験の終了後の吸収瓶を用い，その吸収瓶に熱ガ ス導入後, 乾燥空気を $200 \mathrm{ml} / \mathrm{min}$ の流速で 10 分間導 入する操作を繰り返したところ, Table 1 の右の欄に示 すように 7 回でほぼ恒量となり,かつプラスの総計は左 の欄のマイナスの総計值とほぼ一致した.

Table 2 に実際試料の分析における質量の変化を示 すが，燃焼操作に伴い，吸収瓶の吸収剂に吸着されてい る酸素が脱離し，次の酸素の導入による恒量化操作で脱 離した分だけ酸素が吸着することが分かる．又熱ガスが 最初に入る水吸収瓶の汪らが酸素の吸着する量が大であ る.

本法の場合，加熱されたへリウム及び酸素の吸収瓶へ の導入で，吸収瓶に約 700 カロリーの熱量が持ち込ま 
Table 1 Variation of weights of absorption bottles with two procedures in improved Liebig method

\begin{tabular}{|c|c|c|c|c|c|}
\hline \multicolumn{3}{|c|}{ (1) } & \multicolumn{3}{|c|}{$(2)$} \\
\hline Original & $\mathrm{A} / \mathrm{mg}$ & $\mathrm{S} / \mathrm{mg}$ & Original & $\mathrm{A} / \mathrm{mg}$ & $\mathrm{S} / \mathrm{mg}$ \\
\hline 1 & -11.2 & -22.4 & 1 & +5.0 & +6.3 \\
\hline 2 & +4.0 & +6.0 & 2 & +2.6 & +5.6 \\
\hline 3 & -4.5 & -8.3 & 3 & +1.1 & +2.8 \\
\hline 4 & +9.6 & +14.1 & 4 & +1.4 & +3.1 \\
\hline 5 & -10.3 & -21.9 & 5 & +1.0 & +1.8 \\
\hline 6 & +3.6 & +12.7 & 6 & +0.7 & +1.5 \\
\hline 7 & -3.2 & -10.6 & 7 & +0.5 & +0.8 \\
\hline Total & -12.0 & -30.4 & Total & +12.3 & +21.9 \\
\hline
\end{tabular}

A : absorption bottle packed with magnesium perchlorate; $\mathrm{S}$ : absorption bottle packed with sodium hydroxide. (1) variation of weight with cooling after passing of heated gas to absorption bottle; (2) variation of weight with passing of dried air after passing of heated gas to absorption bottle continued from (1) procedure

れるが，一般に吸着エネルギーは 1 モル当たり数百ない し数千カロリー程度といわれている6) ので, この酸素脱 離現象が起こると推定した.

又以上の結果からみて, シェフィールド高温法の場 合, JIS 法1)では乾燥空気の導入装置を空気置換装置と 記載しているが, 実際には脱離した分の酸素を再び吸着 させるための恒量化装置である.

3.1.2 吸収剤の活性化 試料の燃焼生成ガス中の水 分及び二酸化炭素を吸収させた吸収瓶の恒量化を図るた め乾燥空気を導入する際，とり分け梅雨期から夏季にか けて空気の乾燥剤の吸収能力の低下が早く,この結果と して乾燥の不十分な空気を導入した吸収瓶を用いて試料 の燃焼操作を行らと, 熱ガスの導入に伴い, 水吸収瓶及 び二酸化炭素吸収瓶の各々の吸収剤からの酸素の脱離す る量が大となり, 取り外して乾燥空気を導入しても恒量 化を図れなくなるよって空気を乾燥してから使用する 方式はやめ，水分をほとんど含まないボンベからの酸素
を過塩素酸マグネシウム粒を充てんした吸収瓶を通して 使用する方式を採用した. この場合でも吸収瓶を長期に わたって使用すると吸収剤の水分吸収能力は十分ある状 態でも，この吸収瓶を通過した酸素によって上記の活性 化現象が起こるため, 吸収瓶の過塩素酸マグネシウム粒 は 1 週間ごとに充てんしな拉すことにした.なお導入ガ ス中に水分が含まれていても, 約 $800^{\circ} \mathrm{C}$ に加熱した酸 化銅の層を通してから吸収瓶に導入すると，水分は完全 に水吸収瓶で捕集され，水吸収瓶中の過塩素酸マグネシ ウム粒, 二酸化炭素吸収瓶の水酸化ナトリウム粒ともに 活性化されず, 熱ガス導入後の乾燥空気の導入で恒量化 を図ることができる. 又この現象は著者らが，低石炭化 度炭の水分の直接定量法の検討の際にも認めた7)ことで あるが，このこと自体はリービッヒ法が定量法として成 立する前提である. 又吸収剤の活性化現象はリン酸蒸気 によっても起こることを認めた.すなわちコンポスト有 機質試料を約 90 回連続燃焼後の燃焼管を用い, 試料は燃 焼せず，熱ガスのみを水吸収瓶及び二酸化炭素吸収瓶に 導入し，その後乾燥酸素を導入する恒量化操作を 10 回 繰り返し行ったが，Fig. 3 に示すように，両吸収瓶と もに恒量化を四ることができなかった. この 10 回の質 量変化の正負の和は水吸収瓶(過塩素酸マグネシウム粒) で $+1.2 \mathrm{mg}$, 二酸化炭素吸収瓶 (水酸化ナトリウム粒) で $+8.8 \mathrm{mg}$ であった.この水酸化ナトリウム粒の吸収 剤の全量についてリン酸を定量したところ $7.6 \mathrm{mg}$ の值 が得られ，吸収瓶の質量増 $8.8 \mathrm{mg}$ とほぼ一致した. 文 献8）によれば，ピロリン酸からメタリン酸に濃縮されて も， $850^{\circ} \mathrm{G}$ に共沸点があり，酸化銅は $800^{\circ} \mathrm{G}$ に加熱し ているため, 熱ガスの通過に伴いリン酸の蒸気が発生す るものと考えられる.

以上のことから，リンの含量の高いコンポスト肥料を 分析する場合には, 専用の燃焼管を用い, 燃焼生成ガス はいったんテドラーバッグに捕集し，冷蔵庫で約 5 分間 冷却してリン酸を袋の表面に付着させた後，袋のガスを 水吸収瓶及び二酸化炭素吸収瓶経由でアスピレーターで

Table 2 Amounts of absorbed oxygen in absorption bottle for improved Liebig method

\begin{tabular}{|c|c|c|c|c|c|c|c|c|c|c|}
\hline & & \multirow{2}{*}{$\begin{array}{l}\text { Sample } \\
\text { wt./g }\end{array}$} & \multicolumn{2}{|c|}{ (a) $/ g$} & \multicolumn{2}{|c|}{ (b) $/ g$} & \multicolumn{2}{|c|}{$T\{=(\mathrm{a})+(\mathrm{b})\} / \mathrm{g}$} & \multicolumn{2}{|c|}{$x, \%$} \\
\hline & & & A & $\mathrm{S}$ & A & $\mathrm{S}$ & $\mathrm{A}$ & $S$ & $\mathrm{H}$ & $\mathrm{C}$ \\
\hline Coal & 1 & 0.2462 & 0.0220 & 0.7290 & 0.0762 & 0.0036 & 0.0982 & 0.7326 & 4.46 & 81.14 \\
\hline (Cerro) & 2 & 0.2381 & 0.0193 & 0.7032 & 0.0742 & 0.0035 & 0.0935 & 0.7067 & 4.39 & 81.00 \\
\hline Liquefied & 1 & 0.2186 & 0.0249 & 0.6562 & 0.1065 & 0.0771 & 0.1314 & 0.7333 & 6.73 & 91.55 \\
\hline oil & 2 & 0.2178 & 0.0248 & 0.6378 & 0.1052 & 0.0930 & 0.1300 & 0.7308 & 6.68 & 91.57 \\
\hline
\end{tabular}

$\mathrm{A}$ and $\mathrm{S}$ : same as in Table 1. (a) increase in weight with cooling after combustion; (b) increase in weight with passing of oxygen to absorption bottle; (c) total increase in weight of absorption bottle; (d) analytical value caculated from total increase 


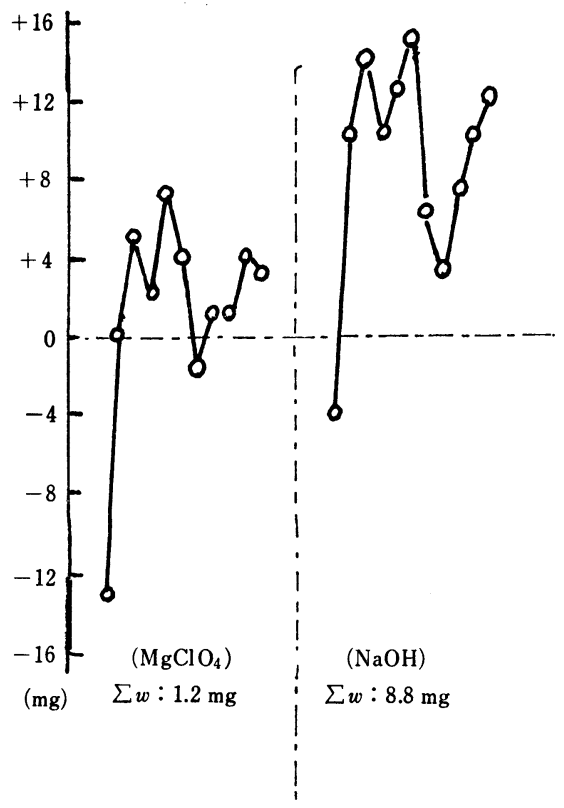

Fig. 3 Variation of weight by activation with phosphoric acid vapor

吸引し，水分，二酸化炭素を各々吸収させ，炭素は二酸 化炭素の吸収による質量増から，水素は水の吸収による 質量増にテドラーバッグの質量増の分を加えて各々定量 する.

\section{2 窒素酸化物の影響}

リービッヒ法では活性二酸化マンガンの吸収瓶を用い て窒素酸化物を除去しないと，炭素の 分析值が $0.17 \%$ (29 試料の平均) 高值を示したといら報告9) や $0.24 \%$ 高値を示したという報告10)がある。

これに対して, シェフィールド高温法では窒素酸化物 の影響は無視でさる程度9) と報告されている。

本法の場合には温度条件はリービッヒ法と同じである が, 酸素の流速はシェフィールド高温法とほぼ同じであ る.よって窒素酸化物の影響について調べた. 試料は平 均的な窒素含量のバルマー炭 $(\mathrm{N}: 1.13 \%)$ と窒素含量 の特に高い砂川炭（N:1.93\%）を用いた.

この両銘柄の石炭について, 窒素酸化物の除去剤とし て，二酸化マンガンを用いた場合と用いない場合の測定 結果を Table 3 に示す.

Table 3 に見られるように，除去剤なしでは，バル マー炭で $0.16 \%$ ，砂川炭で $0.19 \%$ 各々高值を示した.

Table 3 の結果から, 窒素酸化物の影響はほ臣無視
Table 3 Influence of nitrogen dioxide on improved Leibig method

\begin{tabular}{|c|c|c|c|c|c|}
\hline \multirow{2}{*}{ Coal } & & \multicolumn{2}{|c|}{ Without $\mathrm{MnO}_{2}$} & \multicolumn{2}{|c|}{ With $\mathrm{MnO}_{2}$} \\
\hline & & C & $\mathrm{H}$ & C & $\mathrm{H}$ \\
\hline \multirow[t]{4}{*}{ Balmer } & 1 & 79.48 & 4.31 & 79.44 & 4.21 \\
\hline & 2 & 79.71 & 4.26 & 79.43 & 4.23 \\
\hline & mean & 79.60 & 4.28 & 79.44 & 4.22 \\
\hline & Diff. & $C: 0.16$, & $H: 0.06$ & & \\
\hline \multirow[t]{4}{*}{ Sunagawa } & 1 & 75.37 & 5.64 & 75.15 & 5.64 \\
\hline & 2 & 75.37 & 5.63 & 75.23 & 5.62 \\
\hline & mean & 75.37 & 5.64 & 75.18 & 5.63 \\
\hline & Diff. & C : 0.19 , & $\mathrm{H}: 0.01$ & & \\
\hline
\end{tabular}

Figures are expressed in $w t \%$.

できる.しかし正確な分析值を要求されるときには二酸 化マンガンの吸収瓶を用いる必要がある.

\section{3 低石炭化度炭の対策}

褐炭類など，低石炭化度炭は吸湿性が大であり，水分 含量が高く,かつその含量の経時変化による変動が大き い. 又高い水分含量の試料をそのまま分析すると炭素の 分析值が低い值を示す傾向があるため，同一試料につい て水分と炭素・水素の元素分析を連続して分析する方法 を検討した。

装置は Fig. 4 に示したように，燃焼管に乾燥管を取 り付け，この管内を $110^{\circ} \mathrm{C}$ に保持した位置に試料ボー トを挿入し，ヘリウムを $100 \mathrm{ml} / \mathrm{min}$ の流速で導入し， 発生した水分を水吸収瓶に吸収させて測定し, 次いで吸 収瓶を取り替光, 試料ボートはフラッシュヒーターの位 置に移し, 通常の操作で炭素・水素の元素分析を実施す る.

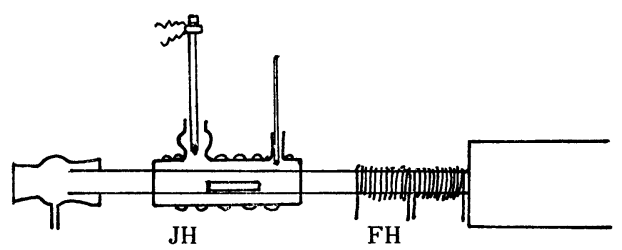

Fig. 4 Apparatus for sequential analysis of moisture, hydrogen and carbon in low lank coal $\mathrm{JH}$ : jacket heater; $\mathrm{FH}:$ flash heater

低石炭化度炭のヤルーン炭, モーエル炭, 太平洋炭の 3 銘柄について測定したが，2 回の繰り返し分析の差の 平均は水分 : $0.15 \%$, 水素 : 0.09\%, 炭素 : $0.11 \%$ で, 測定精度は良好であった。 


\section{4 揮発性油の対策}

低沸点留分の試料では揮発による損失で低值を示すこ とを考慮してその対策を検討した.

試料は Fig. 5 に示した石英製カプセルに試料を注入 してから注入孔にアルミはくをはり，更に挿入時のふく 射熱を遮へいするためニッケル板で被覆した。

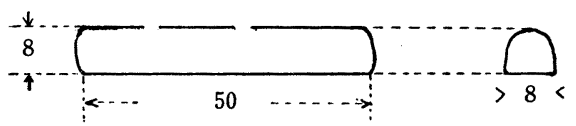

Fig. 5 Dimension of silica tube (mm)

検討には試薬のトルエン (理論值, $\mathrm{C}: 91.31 \%, \mathrm{H}$ : $8.70 \%$ ，純度 $99.0 \%$ をを用いた. 2 回の繰り返し 測定 の結果は, 遮へい板を用いない場合の差は $\mathrm{H}: 0.12 \%$, $\mathrm{C}: 0.56 \%$, 理論值とのバイアスは $\mathrm{H}:+0.09 \%, \mathrm{C}$ : $-0.24 \%$ であったのに対し，遮へい板を用いたときの 差は $\mathrm{H}: 0.17 \%, \mathrm{G}: 0.07 \%$ ，理論值とのバイアスは $\mathrm{H}:+0.24 \%, \mathrm{C}:+0.05 \%$ であり, 遮へい板の効果が 認められた。

又昭和 56 年度実施の「石炭液化油の分析評価之用途 開発」11) に関連して実施した，石炭液化油各留分につい ての炭素・水素の元素分析を本法で実施した結果は, ガ ソリン留分を含めて, 他の 2 分析所が差動熱伝導率法で 測定した結果とよい一致を示した。

\section{交献}

1) JIS M 8813，石炭類及びュークス類の元素分析方 法 (1973).

2) ISO 609, Coal and coke-Determination of carbon and hydrogen-High temperature combustion method.

3) ISO 625, Goal and coke-Determination of carbon and hydrogen-Liebig method.

4) T. Fujimori, K. Ishikawa : Fuel, 51, 120 (1972).

5）斉藤 陽，石井照明：燃協，58，203 (1974).
6) 藤代亮一訳 : “物理化学 (下)”, p. 554 (1964), (東京化学同人).

7）斉藤 陽，田中瑞雄，宮津 隆：燃協，63，1049 (1984).

8) V. Wazer : "Phosphorus and Its Compound", vol. I, p. 774 (1958), (Interscience Publishers, New York).

9) A. H. Edwards : Fuel, 37, 415 (1958).

10) M. P. Mandoza : Fuel, 37, 409 (1958).

11）社団法人燃料協会：“石炭液化油の分析評価々用 途開発”, (1982).

$$
\text { is }
$$

Conditions for constant weight of absorption bottle in determination of carbon and hydrogen by improved Liebig method. Kiyoshi SAITo and Shoji IchidA (Technical Research Center, Nippon Kokan K. K., 1-1, Minamiwatarida-cho, Kawasakiku, Kawasaki-shi, Kanagawa 210)

The improved Liebig method developed by the authors is as follows : a sample is pyrolyzed under passing helium and the evolved volatile matter is oxidized by heated copper dioxide. Then the residues of the sample are burned and the reduced copper is oxidized by passing oxygen. Thus the increase in weights of magnesium perchlorate and caustic soda as absorber for water and carbon dioxide are measured. In this method, the passing of dried oxygen to the absorber after combustion procedure was necessary to get a constant weight. But if the oxygen contained minute amounts of moisture, magnesium perchlorate and caustic soda were activated, making it difficult to get a constant weight. The activation also occurred from the vapor of phosphoric acid. The procedure for the sequential analysis of moisture, carbon and hydrogen in low rank coal and the analysis of volatile liquid fuel were established. The relative standard deviation was $0.2 \%$ for carbon. The time required for each analysis was $20 \mathrm{~min}$.

(Received September 7, 1985)

\section{Keyword phrases}

improved Liebig method; determination of carbon and hydrogen in fuel. 